\title{
Responsibility Of Doctors Who Perform Malpractices (An Overview Under Health Law)
}

\author{
Benny L H Hutahaean \\ North Sumatera University Faculty Of Law. E-mail: bennyl@gmail.com
}

\section{ARTICLE INFO}

Keywords:

Medical Malpractice,

Article history:

Received Sept 21, 2019;

Revised Oct 15, 2019;

Accepted Des 27, 2019;

Online Jan 30, 2020.

\begin{abstract}
The public's trust and positive assessments of the medical world are starting to decline, the medical world that used to seem unreachable by the law can now become a legal problem. This can be seen from the news that is reported by various mass media, both print and electronic media, there are often legal cases both civil and criminal which are examined by the Court related to medical practice or are often mentioned by many groups as: "Malpractice Medical". The problems that will be discussed by the author in writing this thesis are: What are the limitations that can be used to determine that a doctor has committed medical malpractice on a patient; What actions or legal remedies can a patient or his family take if he is exposed to medical malpractice; What sanctions can be imposed on doctors who commit medical malpractice as a form of responsibility of doctors to their patients. The type of research used in this paper is a normative juridical research, namely research conducted on written regulations governing health law and legal materials related to medical malpractice.
\end{abstract}

This is an open access article under the CC BY-NC license.

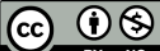

\section{Introduction}

The history of the medical treatment of a doctor is identified with the "healing god" who is glorified by society, because of his ability to know things that are not visible from the outside. Moreover, at that time, there were times when healing from illness was obtained after "the doctor" read prayers for his patients, as clergy do. In subsequent developments along with the development of the human mind and civilization, this element of worship gradually disappeared. However, the position and role of doctors are still considered high by the community. The emergence of a higher position is due to the needs of community members who are sick (patients) in dire need of a doctor's help to heal themselves.

Public respect for the medical profession is higher than other professions in society, such as: traders, police, prosecutors, judges, lawyers, civil servants, and even teachers who provide early education for a doctor while still in school. This can be seen from their socio-economic status, because usually someone who works as a doctor will have enough clothing, food and shelter or in other words, his life can be fulfilled properly.

Society views the medical profession as a noble profession because it relates directly to humans and is related to human life and death, so that every member of the community recognizes that a doctor is a wise person or it can be said that a doctor is a "helping god" in the midst of society. 
For ordinary people there is also an opinion that a doctor will not be able to make mistakes in carrying out his duties, so they surrender completely to doctors. He will obey all the doctor's advice and the doctor may take any medical measures that must be taken against him in the hope of recovering from the disease. If all treatment measures have been carried out by the doctor but the disease does not heal, even the patient dies or in other words the doctor has "failed" to save the patient, then the patient's family assumes that it is a destiny or fate that has been outlined by God and not because of the inability of doctors to treat disease. In the event that the patient dies when the doctor performs a medical action (such as giving an injection, surgery), the public does not even suspect that the disease caused by the patient's death is due to an error made by the doctor. then the patient's family assumes that it is a destiny or fate that has been outlined by God and not because of the doctor's inability to treat the disease. In the event that the patient dies when the doctor performs a medical action (such as giving an injection, surgery), the public does not even suspect that the disease caused by the patient's death is due to an error made by the doctor. then the patient's family assumes that it is a destiny or fate that has been outlined by God and not because of the doctor's inability to treat the disease. In the event that the patient dies when the doctor performs a medical action (such as giving an injection, surgery), the public does not even suspect that the disease caused by the patient's death is due to an error made by the doctor.

Patients or their families often choose to remain silent even though the treatment and health services received from doctors are considered inadequate. They do not dare to express their dissatisfaction to the doctor or take legal action to sue the doctor for fear that the doctor will refuse to cure the patient's illness.

According to Munir Fuady, the factors behind the patient not expressing his dissatisfaction with the bad service provided by the doctor or in other words demanding the doctor who perform the bad service through legal channels, among others.

a. Due to the lack of awareness of patients in Indonesia of their rights as patients.

b. The tendency of Indonesian people to be "nrimo" as it is.

c. Due to the lack of trust from patients in the legal and judicial process in Indonesia.

d. Because of the relatively strong position and finances of doctors and hospitals, which makes patients pessimistic about being able to fight for their rights as patients.

The public's trust and positive assessments of the medical world are starting to decline, the medical world that used to seem unreachable by the law can now become a legal problem. This can be seen from the news that is reported by various mass media, both print and electronic media, there are often legal cases both civil and criminal which are examined by the Court related to medical practice or are often mentioned by many groups as: "Malpractice Medical". Complaints that are often submitted as a form of medical malpractice include: ${ }^{7}$ :

a. Slow medical services, both by doctors, hospitals, and clinics

b. Excessive maintenance costs (expensive)

c. Rejection of patients by the hospital because they cannot afford the down payment.

d. Trend House sick, nor doctor for do examination or action that the patient assesses is not necessary.

The following are some examples of cases suspected of being medical malpractice cases that occurred in Indonesia from 1995 to 2009 : 
Table 1

Examples Of Case Suspected As Medical Malpractice Cases

\begin{tabular}{|c|c|c|c|c|}
\hline NO & VICTIM & CASE & THE PLACE & YEAR \\
\hline 01 & Dian Nita A & $\begin{array}{l}\text { Leg amputated due to wrong } \\
\text { medication }\end{array}$ & $\begin{array}{l}\text { Koesna Hospital } \\
\text { Tuban, East Java }\end{array}$ & 1995 \\
\hline 02 & Meilani Shanti & $\begin{array}{l}\text { Dengue Fever, then surgery and } \\
\text { die }\end{array}$ & $\begin{array}{l}\text { Mother's Jewel Hospital } \\
\text { North Sumatra }\end{array}$ & 1995 \\
\hline 03 & Sriyanti & Died after being injected & $\begin{array}{l}\text { Practice room } \\
\text { Ang Dijn Tjwan }\end{array}$ & 1997 \\
\hline 04 & Lim A Hui & Blind due to wrong blood transfusion & $\begin{array}{l}\text { Your Hope Hospital } \\
\text { Pontianak }\end{array}$ & 1997 \\
\hline 05 & Paradise & Died after being given antibiotics & $\begin{array}{l}\text { Soetomo Hospital } \\
\text { Surabaya }\end{array}$ & 2000 \\
\hline 06 & Chususyanti side & $\begin{array}{l}\text { Bleeding and coma from surgery and } \\
\text { reportoscopy }\end{array}$ & $\begin{array}{l}\text { Budi Jaya Hospital } \\
\text { Jakarta }\end{array}$ & 2000 \\
\hline 07 & Nelly & Blind after tumor surgery on back & $\begin{array}{l}\text { South Jakarta Medistra } \\
\text { Hospital }\end{array}$ & 2000 \\
\hline 08 & Liantia Kaliza & Died due to doctor's negligence & $\begin{array}{l}\text { Mataram Hospital and } \\
\text { RS } \\
\text { Islam Siti Hajar } \\
\text { Mataram }\end{array}$ & 2002 \\
\hline 09 & $\begin{array}{l}\text { Irianti Laode } \\
\text { Dahai }\end{array}$ & $\begin{array}{l}\text { Died due to surgery by a doctor } \\
\text { general }\end{array}$ & $\begin{array}{l}\text { Cenderawasih Tunas } \\
\text { Clinic } \\
\text { Jayakarta }\end{array}$ & 2002 \\
\hline 10 & $\begin{array}{l}\text { Muhammad } \\
\text { Genta }\end{array}$ & $\begin{array}{l}\text { His head was cut by a knife during } \\
\text { surgery } \\
\text { labor }\end{array}$ & $\begin{array}{l}\text { Family Partner } \\
\text { Hospital } \\
\text { Bekasi }\end{array}$ & 2002 \\
\hline 11 & Suwarti & Died after childbirth & $\begin{array}{l}\text { Setiawan Hospital } \\
\text { Bangkalan } \\
\text { Madura }\end{array}$ & 2002 \\
\hline 12 & Sherly & Disability after childbirth & $\begin{array}{l}\text { Libra Citeurup } \\
\text { Hospital }\end{array}$ & 2002 \\
\hline 13 & $\begin{array}{l}\text { Arief Budiyanto, } \\
\text { Syaifuddin }\end{array}$ & Died of $\mathrm{CO} 2$ poisoning & Bengkulu Hospital & 2002 \\
\hline 14 & Irwanto & Paralyzed after being given medicine & $\begin{array}{l}\text { Bintaro International } \\
\text { Hospital } \\
\text { Tangerang }\end{array}$ & 2003 \\
\hline 15 & Josephina & $\begin{array}{l}\text { Died due to stimulant drugs } \\
\text { birth }\end{array}$ & $\begin{array}{l}\text { Bintaro International } \\
\text { Hospital } \\
\text { Tangerang }\end{array}$ & 2003 \\
\hline 16 & $\begin{array}{l}\text { Adya } \\
\text { Fitri } \\
\text { Harisusa } \\
\text { nti }\end{array}$ & $\begin{array}{l}\text { Wrong diagnosis } \\
\text { Bleeding in the uterus turns out to be } \\
\text { in the intestines }\end{array}$ & $\begin{array}{l}\text { Bogor PMI Hospital } \\
\text { PELNI } \\
\text { RSCM . } \\
\text { Hospital }\end{array}$ & 2003 \\
\hline 17 & Asri Muliasari & $\begin{array}{l}\text { Died after gland surgery } \\
\text { spleen }\end{array}$ & $\begin{array}{l}\text { Wahidin Hospital } \\
\text { Sudirohusodo } \\
\text { Makassar }\end{array}$ & 2003 \\
\hline 18 & Lucy Maywati & $\begin{array}{l}\text { Died during cesarean delivery and } \\
\text { hospital } \\
\text { embezzle Medical Record }\end{array}$ & $\begin{array}{l}\text { YPK Maternity } \\
\text { Hospital } \\
\text { Jakarta }\end{array}$ & 2004 \\
\hline 19 & Wulan Yulianti & Died due to bowel surgery & RSCM Jakarta & 2004 \\
\hline 20 & Jeremiah & $\begin{array}{l}\text { Caesarean section resulted in injuries } \\
\text { and disabilities }\end{array}$ & $\begin{array}{l}\text { Budi Lestari Hospital } \\
\text { Bekasi } \\
\text { Hermina Hospital } \\
\text { Bekasi }\end{array}$ & 2004 \\
\hline 21 & $\begin{array}{l}\text { Mindo } \\
\text { Sihombing }\end{array}$ & Hernia surgery failed & $\begin{array}{l}\text { Friendship Hospital } \\
\text { Jakarta }\end{array}$ & 2004 \\
\hline 22 & Robinson L & Permanent disability after surgery & Bukit Barisan Military & 2004 \\
\hline
\end{tabular}




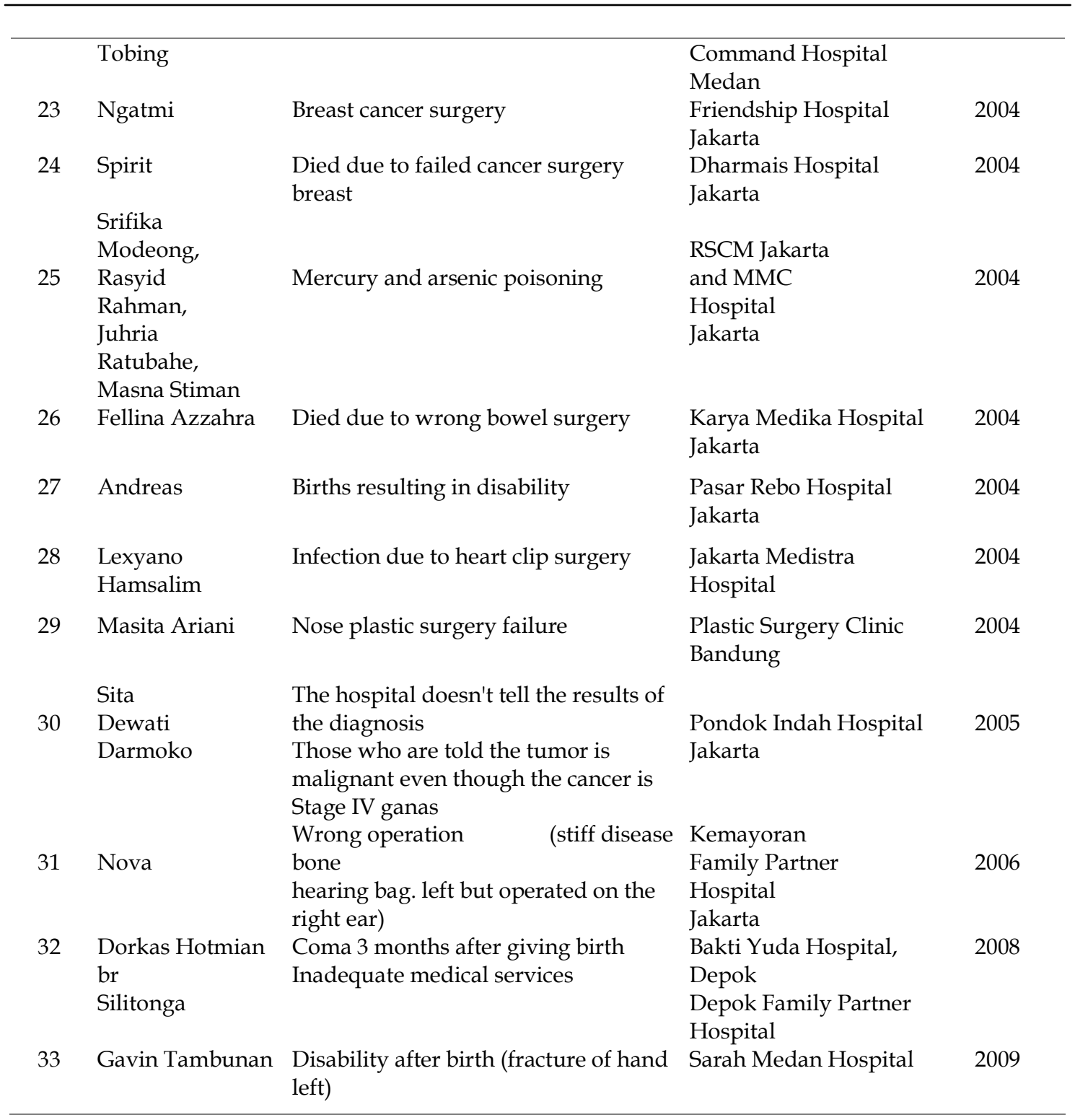

Medical malpractice claims submitted by the public to the court for doctors are considered a threat, the application of law in the medical field is considered a legal intervention, the doctors consider that all their actions can be justified because medical actions are carried out on the basis of helping patients and the Indonesian Medical Code of Ethics has it is enough to regulate and supervise doctors in their work so that there is no need for legal intervention.

\section{Method}

\subsection{Types of research}

The type of research used in this paper is a normative juridical research, namely research conducted on written regulations governing health law and legal materials related to medical malpractice.

\subsection{Data analysis}

The data analysis carried out in this paper is qualitative, namely what is obtained from field research and interviews conducted in writing and orally which are thoroughly and thoroughly researched. 


\section{Analysis and Results}

\subsection{Making a Complaint to MKDKI}

The first legal remedy that a patient or his family can take if they feel they have experienced malpractice by a doctor is to file a complaint with the MKDKI. MKDKI is an autonomous institution from KKI which was formed to enforce the discipline of doctors in the implementation of medical practice.

One of the main tasks of the MKDKI as stated in Article 64 of the Medical Practice Law is to "receive complaints, examine, and decide cases of violations of physician discipline". Based on the article, it can be said that the MKDKI is the authorized institution to determine whether or not there are errors made by doctors in the application of medical disciplines; and establish sanctions for dentists who are found guilty. Discipline violations are violations of the rules and/or provisions of the application of science, which can essentially be grouped into 3 things, namely:

a. Implementing medical practice incompetently

b. Professional duties and responsibilities to patients are not carried out properly

c. Disgraceful behavior that damages the dignity and honor of the medical profession

\subsection{Trough Criminal Court}

Patients or their families can report a doctor to the police if in practice the doctor has committed an act of medical malpractice which can be qualified as an act that violates the provisions of the Criminal Code, including: sexual assault (article 284), negligence causing death (article 359), negligence causing death. serious injury (article 360), leaving people who need help (article 322) etc.

The increasing number of public complaints against medical malpractice actions that are often reported by the mass media when examined are generally acts of negligence by doctors when practicing medical which causes other people to suffer injuries (disability) and die as regulated in articles 359 and 360 of the Criminal Code.

Based on the complaint, the Police will conduct an investigation to determine the complaint is a criminal act. After the investigation has been carried out and it is found that it is a criminal act, then the Police will carry out investigative actions with the aim of collecting evidence, witnesses related to the crime and to find the suspect who committed the crime. After the evidence is collected, the investigator (police) will pour it into the Minutes of Investigation (BAP) and then submit it to the Public Prosecutor (Prosecutor) to be studied and examined for completeness. The BAP will later become the basis for the Public Prosecutor to make an indictment, therefore if the Public Prosecutor feels that the BAP is incomplete, it can be returned to the investigator to be completed.

\subsection{Doing a Lawsuit Against a Doctor to Civil Court}

The legal relationship that occurs between a doctor and a patient in a medical practice is included in the engagement, therefore medical practice is a civil law study. The position of doctors and patients in therapeutic transactions is equal, therefore patients can file lawsuits against doctors who commit medical malpractice. Civil malpractice occurs when in a medical practice the patient feels aggrieved by the actions taken by the doctor, so he has the right to file a claim for compensation as compensation for the losses he has incurred through the Civil Court.

Patients who are victims of medical malpractice choose the civil route by filing a lawsuit against a doctor based on a default or an act against the law must prove the existence of an error on the part of the perpetrator (the doctor or the defendant) either by intention or negligence so that the act is included in an unlawful act. . In general, patients have difficulty in 
proving that what they suffer is the result of a doctor's error and/or negligence in carrying out medical practice. This difficulty arises because the patient does not have sufficient knowledge about the therapy and diagnosis made by the doctor to him; especially in the case of a surgical patient who is given anesthetic causing the patient not to know the actions taken when the doctor performs surgery, because the patient is in an unconscious state (under the influence of anaesthesia). Therefore, to protect the legal interests of patients who are harmed by health services, some scholars propose to apply the doctrine of Res Ipsa Loquitur (The thing speak for it self).

\section{Conclusion}

Medical malpractice is every action of a doctor (whether intentionally or unintentionally such as negligence, negligence) in carrying out a medical practice, which is not in accordance with medical ethics, medical professional standards, applicable laws and regulations so as to cause harm to the patient such as pain, injury, disability, death and other loss; and for his actions, the doctor must be responsible under administrative law and/or civil law and/or criminal law. 1 Legal remedies that can be taken by patients (or their families) who experience medical malpractice actions consist of: (a) Make a complaint to the MKDKI which based on Law Number 29 of 2004 concerning Medical Practice is the authorized institution to determine whether or not there are errors made by doctors in the application of medical disciplines; and (b) establish sanctions for dentists who are found guilty. (c) Suing a doctor who commits medical malpractice through the Civil Court is related to the patient's loss due to the medical malpractice act. report the doctor who performs medicine to the Police which will later be forwarded to the Public Prosecutor and until finally the doctor's malpractice action will be examined and decided in the Criminal Court. 2.Doctors who commit medical malpractice may be subject to sanctions based on administrative law and/or civil law and/or as a form of legal liability as follow, (a) Sanctions based on Administrative Law contained in the Medical Practice Law: Written warning; Recommendation for Revocation of Registration Certificate (STR) or Temporary Practice Permit (SIP) for a maximum of 1 year; Recommendation for Revocation of Registration Certificate (STR) or Practice License (SIP) permanently or permanently; Obligation to attend education or training in medical education institutions which can be in the form of: Formal education; or Training in knowledge and/or skills, internship in educational institutions or network health service facilities or designated health service facilities for a minimum of 3 months and a maximum of 1 year. (b) Sanctions based on Civil Law: Pay compensation as a result of the medical malpractice. (c) Sanctions based on Criminal Law: Given to doctors who violate the provisions of the Criminal Code and laws and regulations relating to medical practice, including imprisonment, fines.

\section{References}

Veronica D Komalawati, Law and Ethics in Medical Practice, Sinar Harapan Library, Jakarta, 1989.

Anny Isfandyarie, Malpractice \& Medical Risk in Criminal Law Studies, Library Publisher; Malang, 2005.

Ninik Maryanti, Medical Malpractice in terms of Criminal and Civil Law, Bina Aksara Publisher; Jakarta, 1988.

Anny Isfandyarie, Malpractice \& Medical Risks in Criminal Law Studies, op.cit.

Munir Fuady, Hippocratic Oath (Legal Aspects of Medical Malpractice), Image Publisher Aditya Bakti, Bandung, 2005.

Veronica D Komawalati, The Role of Informed Consent in Therapeutic Transactions: Consent in DoctorPatient Relations, A Juridical Review, op.cit.

Anny Isfandyarie; Malpractice \& Medical Risks in Criminal Law Studies, op.cit. 
Obtained from several sources, including: www.legalonline.com; www.gatra.com; www.vivanews.com; www.okezone.com; www.liputan6.com; www.harian-global.com.

http://id.wikipedia.org?wiki/kedokteran.

Danny Wiradharma, Medical Professional Ethics, Trisakti University Publisher, Jakarta, 2001, pp. 71-73.

http://id.wikipedia.org/wiki/dokter.

Veronica D Komalawati, The Role of Informed Consent in Therapeutic Transactions: Consent in DoctorPatient Relationships, Citra Aditya Bakti Publisher, Bandung 2002.

Bahder Johan Nasution, Health Law: Physician Liability, PT Rineka Cipta, Jakarta, 2005.

Danny Wiradharma, op.cit, pp.

Anny Isfandyarie, Legal Responsibilities and Sanctions for Doctors Book I, Publisher of Achievement Pustaka Publisher, Malang, 2006.

M Jusuf Hanafiah \& Amri Amir, Medical Ethics and Health Law third edition, EGC Medical Book Publisher, Jakarta 1999.

Anny Isfandyarie Legal Responsibilities and Sanctions for Doctors Book I, op.cit.

Anny Isfandyarie, Malpractice and Medical Risk, op.cit,

Veronica D Komalawati, op.cit.

Medical Law (Medical Law) in some literature is often also referred to as Medical Law, Health Law (Health Law, Gezondheisrecht).

J Guwandi, Medical Law, FK UI Publishing Center, Jakarta 2005.

Amri Amir, Second edition of Forensic Medicine Series, Section of Forensic Medicine, USU Faculty of Medicine, Medan 2005, pp. 1-7 